\title{
PENGARUH KEPEMIMPINAN DAN KOMPENSASI TERHADAP KINERJA KARYAWAN PADA PT. PENTA ARTHA IMPRESSI AREA TANGERANG SELATAN
}

\author{
Risza Putri Elburdah \\ Dosen Fakultas Ekonomi Universitas Pamulang \\ Email : dosen01022@unpam.ac.id
}

\begin{abstract}
ABSTRAK
Penelitian ini bertujuan guna mengetahui secara parsial pengaruh kepemimpinan terhadap kinerja karyawan, mengetahui secara parsial kompensasi terhadapkinerja karyawan dan mengetahui secara simultan pengaruh kepemimpinan dan kompensasi terhadap kinerja karyawan pada PT. Penta Artha Impressi Area Tangerang Selatan.

Penulisan dalam penelitian ini bersifat deskriptif kuantitatif dengan pengujian Hipotesis. Responden yang didapat sebanyak 50 karyawan dihitung menggunakan rumus jenuh yang artinya sampel merupakan jumlah dari populasi keseluruhan. Terlebih dahulu dilakukan uji validitas dan reliabilitas sebelum kuesioner disebar untuk seluruh sampel, yang selanjutnya baru diolah sesuai kebutuhan analisa.

Berdasarkan penelitian diperoleh secara parsial Kepemimpinan berpengaruh positif dan signifikan terhadap Kinerja Karyawan dengan nilai t hitung sebesar 9,635 lebih besar dari nilai t tabel yaitu 1,675. Secara parsial Kompensasi tidak mempunyai pengaruh positif terhadap Kinerja Karyawan dengan nilai $t$ hitung sebesar 0,527 yang lebih rendah dari nilai t tabel sebesar 1,675. Secara simultan Kepemimpinan dan Kompensasi mempunyai pengaruh secara bersama-sama terhadap kinerja karyawan, hal ini diketahui dari nilai $\mathrm{F}$ hitung $=47,639$ yang lebih tinggi dari nilai $\mathrm{F}$ tabel yaitu 2,78. Diperoleh persamaan regresi yang terbentuk adalah : $Y=7,418+0,724 X 1+0,111 X 2$ dan berdasarkan uji regresi linier berganda diketahui nilai $R$ Square $\left(R^{2}\right)$ sebesar 0,670 yang termasuk kategori kuat. Kesimpulan dari penelitian ini adalah secara simultan kedua variabel berpengaruh positif terhadap kinerja sebesar 67\%, sedangkan 33\% sisanya dipengaruhi oleh faktor-faktor lain yang tidak dilakukan pada penelitiaan ini.
\end{abstract}

\section{Kata kunci : Kepemimpinan, Kompensasi, Kinerja Karyawan.}

\section{ABSTRACT}

The purpose of this study is to partially determine leadership on employee performance, to know partially compensation for employee performance and to know simultaneously between leadership and compensation to employee performance at PT. Penta Artha Impressi Area, South Tangerang.

The writing technique in this research is quantitative descriptive with hypothesis testing. Respondents obtained as many as 50 employees are calculated using the saturation formula which means the sample is the sum of the overall 
population. First the validity and reliability tests are carried out before the questionnaire is distributed to all samples, which are then processed according to the needs of the analysis.

Based on research partially obtained Leadership has a positive and significant effect on Employee Performance with a t value of 9.635 greater than $t$ table value of 1.675. Partially Compensation has no positive effect on employee performance with a $t$ value of 0.527 which is lower than the t table value of 1.675. Simultaneously Leadership and Compensation have a joint effect on employee performance, this is known from the calculated $F$ value $=47.639$ which is higher than the $F$ table value of 2.78. Obtained the formed regression equation is: $Y=$ $7,418+0,724 X 1+0,111 X 2$ and based on multiple linear regression tests it is known that the $R$ Square (R2) value of 0.670 is included in the strong category. The conclusion of this study is that both variables simultaneously have a positive effect on performance by $67 \%$, while the remaining $33 \%$ are influenced by other factors not carried out in this study.

\section{Keywords: Leadership, Compensation, Employee Performance.}

\section{PENDAHULUAN}

\section{A. Latar Belakang}

Investasi terbesar dari suatu organisasi seperti perusahaan adalah sumber daya manusia yang kompeten. Adanya sumber daya manusia yang berkualitas akan menjadi nilai utama suatu perusahaan dibandingkan dengan nilai fisik yang telihat. Kompetensi dan keterampilan yang dimiliki oleh sumber daya manusia merupakan variabel utama yang dixari oleh setiap perusahaan Oleh karena itu sumber daya manusia memiliki peranan penting dalam setiap langkah yang diambil perusahaan.

Keberhasilan suatu organisasi dipengaruhi oleh peran sumber daya manusianya dalam menjalankan fungsinya. Dalam upaya mengembangkan fungsinya, perusahaan atau organisasi memerlukan sumber daya manusia yang berkualitas. Disamping itu juga dibutuhkan keterampilan tinggi dalam melaksanakan fungsi-fungsi perusahaan. Pihak perusahaan dituntut meningkatkan kualitas sumber daya manusia sekaligus meningkatkan pendapatan bagi perusahaan. Hal ini bertujuan agar perusahaan dapat bertahan dan bersaing di pasar global. Meningkatnya pendapatan perusahaan dapat berpengaruh terhadap meningkatnya kinerja karyawan. Kinerja karyawan ini berhubungan erat dengan efektifitas, efisiensi serta sikap karyawan. Ketepatan waktu penyelesaian tugas serta hasil kerja yang sesuai dengan tuntutan merupakn tolak ukur dari suatu efektivitas kinerja. Sedangkan efisiensi dapat diukur dari ketepatan waktu serta biaya yang dikeluarkan untuk mencapai hasil kerja yang telah ditentukan.

Hasil kerja ini berkaitan dengan Kinerja karyawan. Perusahaan tentu mengharapakan kinerja tinggi dengan sumberdaya yang minimal. Karyawan PT. Penta Artha Impressi Area Tangerang Selatan memiliki tanggung jawab untuk menyelesaikan tugas yang menjadi kewajibannya. Apabila kewajibanya terselasaikan dengan baik, maka akan mendapatkan haknya. Salah 
satu cara untuk mengukur terselesaikannya kewajiban tersebut adalah melalui respon positif konsumen yang datang kembali.

Kembalinya konsumen ini menandakan puas atau percayanya terhadap hasil kerja yng dilakukan karyawan, yang pada akhirnya akan berujung pada tercapainya target yang optimal.Hal ini tak lepas dari peran seorang pemimpin. Setiap pemimpin memiliki cara menjalankan kepemimpinannya. Pemimpin disini memiliki peran strategik didalam tercapainya kinerja yang positif. Meningkatnya kinerja bisa tercapai dengan kepemimpinan yang baik. Seoramg pemimpin harus mampu membangun kebersamaan dan kepercayaan setiap bawahan yang dipimpin. Uniknya setiap pemimpin memiliki caranya tersendiri dalam menjalankan kepemimpinannya, pola pikir yang berbeda serta cara mengarahkan bawahan untuk mencapai tujuan. Cara ini biasa disebut dengan gaya kepemimpinan. Gaya kepemimpinan ini bisa disesuaikan dengan kondisi dan karakter bawahan. Beberapa gaya yang terkenal adalah gaya telling, gaya selling dan gaya participating. Gaya-gaya inilah yang menjadi ciri khas antara pemimpin yang satu dan yang lain. Pemimpin yang bertanggung jawab dalam tugas dan fungsinya adalah yang dapat menggerakan bawahan untuk mencpai target kinerja pada perusahaan tempat bekerja. Selain itu mampu memahami keinginan dan kebutuhan dari bawahan tersebut.

Para pemimpin melakukan upaya dalam pengembangan SDM yang ada di perusahaannya dengan memberikan dorongan semangat dari luar dengan tujuan meningkatkan kinerjanya. Salah satu cara yang dapat dilakukan adalah memberikan hak mereka seperti gaji secara tepat waktu serta memberikan kesempatan kepada karyawan untuk maju dan berkembang di karirnya. Bagaimana cara pemimpin dan perusahaan dapat mengelola hal ini menjadi tantangan tersendiri. Pada akhirnya peran pemimpin yang mampu mengelola SDM akan mampi menghantarkan perusahaan mencapai kinerja yang tinggi.

Setiap karyawan dalam suatu perusahaan memiliki kinerja yang berbeda-beda. Pemimpin tidak dapat melakukan cara yang sama dalam mengelola karyawannya. Hal ini bisa terjadi karena faktor individu itu sendiri dan faktor eksternal.

Pada penelitian yang dilakukan oleh Widianto (2018) tentang pengaruh kepemimpinan terhadap kinerja karyawan PT. Bank Tabungan Negara (Persero) Kantor Cabang Utama Makassar. Hasil penelitian menemukan bahwa terdapat pengaruh yang signifikan antara gaya kepemimpinan terhadap kinerja karyawan. Dari hasil yang didapat menyatakan bahwa kompensasi serta kepemimpinan adalah faktor yang dapat mempengaruhi semangat kerja karyawan dalam suatu perangkat organisasi atau perusahaan. Peran seorang pemimpin dalam menerapkan kepemimpinannya akan sangat beroengaruh terhadap keefektifan para karyawan dalam bekerja.

PT. Penta Artha Impressi setiap bulannya memberikan gaji sejumlah Rp. 2.500.000, lalu dengan insentif setiap 3 bulan sekali yang tergantung target di bengkel tersebut, lalu juga dengan lembur setiap 1 bulan sekali, Rp. 20.000/ perjam terakhir tunjangan yang diberikan setiap akhir tahun juga tidak menentu. Dari penjelasan tersebut dapat 
dilihat bahwa dari segi gaji belum sesuai dengan ketetapan UMR Kota Tangerang Selatan.

\section{B. Identifikasi Masalah}

1. Kurangnya kepercayaan pemimpin perusahaan terhadap karyawan.

2. Lambatnya pemimpin dalam pengambilan keputusan sehingga terjadi permasalahan di perusahaan.

3. Kurangnya pemimpin

kesadaran terhadap perusahaan pemilihan karyawan.

4. Kurangnya pemberian kompensasi terhadap kinerja yang dilakukan pada PT. Penta Artha Impressi Area Tangerang Selatan.

5. Sering terlambatnya pemberian tunjangan.

6. Belum optimalnya kinerja karyawan untuk mencapai targetyang telah ditetapkan perusahaan

7. Kinerja karyawan dirasa kurang optimal.

\section{Rumusan Masalah}

1. Apakah terdapat pengaruh signifikan antara kepemimpinan terhadap kinerja karyawan pada PT. Penta Artha Impressi Area Tangerang Selatan?

2. Apakah terdapat pengaruh signifikan antara kompensasi terhadap kinerja karyawan pada PT. Penta Artha Impressi Area Tangerang Selatan?

3. Besar pengaruh signifikan kepemimpinan dan kompensasi secara bersamasama terhadap kinerja karyawan pada PT. Penta Artha Impressi Area Tangerang Selatan?

\section{TINJAUAN PUSTAKA}

\section{A. Kepemimpinan}

\section{Pengertian Kepemimpinan}

Kepemimpinan merupakan tingkah laku maupun cara yang dilakukan oleh seorang pemimpin. Seorang pemimpin dapat diukur kepemimpinannya berdasarkan kemampuan dan kesiapan dalam mempengaruhi, menuntun, menggerakan, dan mengarahkan seseorang atau sekelompok agar merespon suatu pengaruh. Pada dasarnya kepemimpinan meliputi proses mempengaruhi dalam menentukan tujuan organisasi atau instansi, memotivasi perilaku bawahan untuk mencapai tujuan, mempengaruhi untuk perbaikan kelompok.

Menurut Veitzhal Rivai (2014:53) kepemimpinan merupakan cara seseorang mempengaruhi orang lain dengan memberikan umpan yang positif dalam diri orang yang dipimpinnya agar tergerak untuk melakukan suatu peubahan dengan harapan mencapai tujuan yang diinginkan.

\section{Kompensasi}

\section{Pengertian Kompensasi}

Kompensasi merupakan imbalan yang diterima karyawan atas hasil kerja yang dilakukan untuk meningkatkan kinerja organisasi/perusahaan. Kompensasi merupakan hak setiap karyawan. Seorang karyawan yang telah melakukan kewajibannya berhak mendapatkan kompensasi baik itu yang diterima secara fisik, maupun kelebihan lain yang dapat dirasakan (non fisik).

Gary Dessler (2013:46) menyatakan kompensasi yang diterima karyawan merupakan bentuk pembayaran atau 
hadiah yang diberikan kepada karyawan yang muncul dari pekerjaan mereka.

\section{B. Kinerja}

\section{Pengertian Kinerja}

Kinerja karyawan merupakan hasil kerja seseorang atau sekelompok orang didalam perusahaan yang sesuai dengan wewenang serta tanggung jawabnya dalam rangka mencapai tujuan yang diinginkan perusahaan secara transparan dan tidak bertentangan dengan hukum

Menurut Sinambela, dkk (2012) menyatakan kinerja karyawan diartikan sebagai kemampuan karyawan dalam melakukan suatu aktifitas tertentu. Melalui kinerja dapat diketahui upaya yang telah dilakukan karyawan dalam menyalurkan kemampuannya untuk melaksanakan tugas yang menjadi tanggung jawabnya sesuai dengan deskripsi pekerjaan. Oleh karena itu diperlukan kriteria atau dasar yang jelas serta terukur yang disepakati bersama yang menjadi pedoman dalam pelaksanaan tugasnya.

\section{Hipotesis}

1) $\mathrm{H}_{1}=\beta=0$, Diduga tidak terdapat pengaruh variabel kepemimpinan $\left(\mathrm{X}_{1}\right)$ terhadap kinerja kerja karyawan (Y).

$\mathrm{Ha}_{1}=\beta \neq 0$, Diduga terdapat pengaruh variabel kepemimpinan $\left(\mathrm{X}_{1}\right)$ terhadap kinerja kerja karyawan $(\mathrm{Y})$.

2) $\mathrm{HO}_{2}=\beta=0$, Diduga tidak terdapat pengaruh variabel kompensasi $\left(\mathrm{X}_{2}\right)$ terhadap kinerja kerja karyawan $(\mathrm{Y})$.

$\mathrm{Ha}_{2}=\beta \neq 0$, Diduga terdapat pengaruh variabel kompensasi $\left(\mathrm{X}_{2}\right)$ terhadap kinerja kerja karyawan(Y).

3) $\mathrm{HO}_{3}=\beta=0$, Diduga tidak terdapat pengaruh variabel kepemimpinan $\left(\mathrm{X}_{1}\right) \quad$ dan kompensasi $\left(\mathrm{X}_{2}\right) \quad$ terhadap kinerja karyawan (Y).

$\mathrm{Ha}_{3}=\beta \neq 0$, Diduga terdapat pengaruh variabel kepemimpinan $\left(\mathrm{X}_{1}\right)$ dan kompensasi $\left(\mathrm{X}_{2}\right)$ terhadap kinerja karyawan (Y).

\section{METODOLOGI PENELITAN}

\section{A. Ruang Lingkup Penelitaan}

\section{Tempat Penelitian}

Penelitian dilakukan pada PT. Penta Artha Impressi berada di jalan Siliwangi $18 \mathrm{Rt}$ 001 Pamulang Barat Kota Tangerang Selatan,

\section{Waktu Peneltian}

Penelitian ini dilakukan selama 3 bulan, mulai dari bulan September hingga November 2019. Penelitian ini secara bertahap diawali dengan persiapan peneliatian berupa (penulisan proposal judul penelitian, seminar proposal judul skripsi, pengajuan surat izin, pembuatan kuesioer, konsultasi, penyebaran kuesioner, pengolahan data, dan penyusunan skripsi..

\section{B. Populasi dan Sampel}

\section{Populasi}

Populasi dari penelitian ini merupakan seluruh karyawan PT. Penta Artha Impressi yang berjumlah 50 orang karyawan.

\section{Sampel}

Sampel yang dijadikan objek dalam peneitian ini adalah seluruh karyawan di PT. Penta Artha Impressi yang berjumlah 50 karyawan.

\section{Metode Analisis Data}

1. Uji Validtas

2. Uji Reliabilitas 
3. Uji Asumsi Klasik Linearitas)

\section{a. Uji Normalitas}

b. Uji Multikolineritas

c. Uji Heteroskedastisitas

4. Uji Regresi Linier Sederhana

5. Uji Regresi Linier Berganda

6. Koefisien Korelasi

7. Koefisien Determinasi

8. Uji Hipotesis

a. Uji Slimutan(Uji F)

b. Uji Parsial (Uji T)

\section{HASIL PENELITIAN DAN PEMBAHASAN}

1. Teknik Uji Analisis Data a. Uji Kualitas Data 1.) Uji Validitas

Hasil Uji Validitas Variabel Kepemimpinan(X1)

\begin{tabular}{|c|l|c|c|c|}
\hline $\begin{array}{c}\mathbf{N} \\
\mathbf{o}\end{array}$ & $\begin{array}{c}\text { Pernyataa } \\
\mathbf{n}\end{array}$ & $\begin{array}{c}\text { rhitun } \\
\boldsymbol{g}\end{array}$ & rtabel & $\begin{array}{c}\text { Keterang } \\
\text { an }\end{array}$ \\
\hline 1 & Kep_1 & 0.786 & 0,235 & Valid \\
\hline 2 & Kep_2 & 0.782 & 0,235 & Valid \\
\hline 3 & Kep_3 & 0.897 & 0,235 & Valid \\
\hline 4 & Kep_4 & 0.878 & 0,235 & Valid \\
\hline 5 & Kep_5 & 0.616 & 0,235 & Valid \\
\hline 6 & Kep_6 & 0.678 & 0,235 & Valid \\
\hline 7 & Kep_7 & 0.654 & 0,235 & Valid \\
\hline 8 & Kep_8 & 0.837 & 0,235 & Valid \\
\hline 9 & Kep_9 & 0.856 & 0,235 & Valid \\
\hline 1 & Kep_10 & 0.670 & 0,235 & Valid \\
0 & & & & \\
\hline
\end{tabular}

Hasil Uji Validitas Variabel Kompensasi(X2)

\begin{tabular}{|c|l|c|c|c|}
\hline $\begin{array}{c}\text { N } \\
\text { o }\end{array}$ & $\begin{array}{c}\text { Pernyata } \\
\text { an }\end{array}$ & $\begin{array}{c}\text { rhitun } \\
\text { g }\end{array}$ & rtabel & $\begin{array}{c}\text { Keterang } \\
\text { an }\end{array}$ \\
\hline 1 & Komp_1 & 0.838 & 0,235 & Valid \\
\hline 2 & Komp_2 & 0.650 & 0,235 & Valid \\
\hline 3 & Komp_3 & 0.741 & 0,235 & Valid \\
\hline 4 & Komp_4 & 0.822 & 0,235 & Valid \\
\hline 5 & Komp_5 & 0.854 & 0,235 & Valid \\
\hline 6 & Komp_6 & 0.869 & 0,235 & Valid \\
\hline 7 & Komp_7 & 0.806 & 0,235 & Valid \\
\hline 8 & Komp_8 & 0.839 & 0,235 & Valid \\
\hline 9 & Komp_9 & 0.506 & 0,235 & Valid \\
\hline 1 & Komp_1 & 0.785 & 0,235 & Valid \\
0 & 0 & & & \\
\hline
\end{tabular}

Hasil Uji Validitas Variabel Kinerja $\operatorname{Karyawan}(\mathbf{Y})$

\begin{tabular}{|c|c|c|c|c|}
\hline No & $\begin{array}{c}\text { Pernyataa } \\
\mathbf{n}\end{array}$ & rhitung & rtabel & $\begin{array}{c}\text { Keteranga } \\
\text { n }\end{array}$ \\
\hline 1 & KK_1 & 0.852 & 0,235 & Valid \\
\hline 2 & KK_2 & 0.693 & 0,235 & Valid \\
\hline 3 & KK_3 & 0.732 & 0,235 & Valid \\
\hline 4 & KK_4 & 0.807 & 0,235 & Valid \\
\hline 5 & KK_5 & 0.912 & 0,235 & Valid \\
\hline 6 & KK_6 & 0.864 & 0,235 & Valid \\
\hline 7 & KK_7 & 0.814 & 0,235 & Valid \\
\hline 8 & KK_8 & 0.852 & 0,235 & Valid \\
\hline 9 & KK_9 & 0.555 & 0,235 & Valid \\
\hline 10 & KK_10 & 0.810 & 0,235 & Valid \\
\hline
\end{tabular}

2.) Uji Reliabilitas

Hasil Uji Reliabilitas Variabel Kepemimpinan(X1)

Reliability Statistics

\begin{tabular}{|c|c|}
\hline Cronbach's Alpha & $\mathrm{N}$ of Items \\
\hline .938 & 10 \\
\hline \multicolumn{2}{|c|}{$\begin{array}{l}\text { Hasil Uji Reliabilitas Variabel } \\
\text { Kompensasi (X2) }\end{array}$} \\
\hline \multicolumn{2}{|c|}{ Reliability Statistics } \\
\hline Cronbach's Alpha & $\mathrm{N}$ of Items \\
\hline .937 & 10 \\
\hline \multicolumn{2}{|c|}{$\begin{array}{l}\text { Hasil Uji Reliabilitas Variabel } \\
\text { Kinerja Karyawan (Y) }\end{array}$} \\
\hline \multicolumn{2}{|c|}{ Reliability Statistics } \\
\hline Cronbach's Alpha & $\mathrm{N}$ of Items \\
\hline .945 & $\overline{10}$ \\
\hline
\end{tabular}

b. Uji Asumsi Klasik

1.) Uji Normalitas

Hasil Uji Normalias Data

One-Sample Kolmogorov-Smirnov Test

\begin{tabular}{llr} 
& & $\begin{array}{r}\text { Unstandardi } \\
\text { zed Residual }\end{array}$ \\
\hline $\mathrm{N}$ & & 50 \\
\hline Normal Parameters ${ }^{\mathrm{a}, \mathrm{b}}$ & Mean & .0000000 \\
\cline { 2 - 3 } & $\begin{array}{l}\text { Std. } \\
\text { Deviation }\end{array}$ & 2.89877198 \\
\hline Most Extreme & Absolute & .122 \\
\cline { 2 - 3 } Differences & Positive & .096 \\
\cline { 2 - 3 } & Negative & -.122 \\
\hline Test Statistic & & .122 \\
\hline Asymp. Sig. (2-tailed) & & $.062^{\mathrm{c}}$ \\
\hline
\end{tabular}


a. Test distribution is Normal.

b. Calculated from data.

c. Lilliefors Significance Correction.

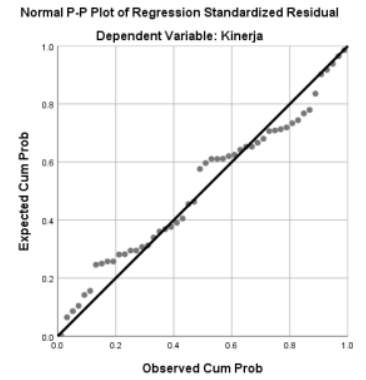

P-Plot Uji Normalitas Data

2.) Uji Multikolinearitas Hasil Uji Multikolinearitas

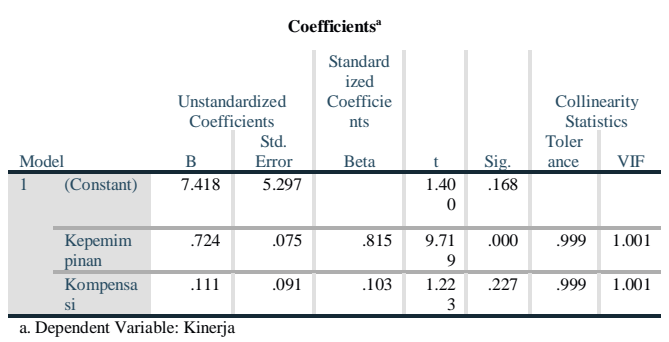

3.) Uji Heterokedastisitas

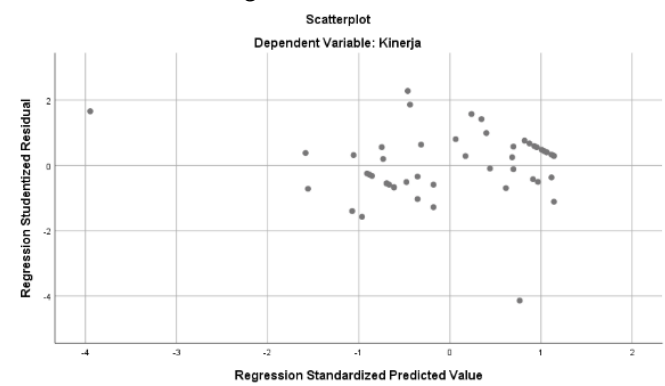

Histogram Uji Heterokedastisitas

2. Regresi Linier Sederhana Hasil Uji Regresi Sederhana

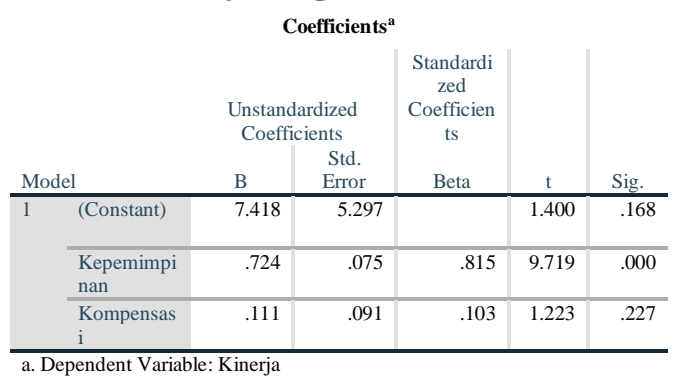

Dari tabel di atas, diperoleh hasil perhitungan sebagai berikut:

$Y=7,418+0,724 X 1$
Sehingga persamaan regresi sederhana yang terbentuk diatas dapat disimpulkan bahwa :

Variabel kepemimpinan mempunyai koefisien bertanda positif terhadap variabel kinerja karyawan dengan nilai sebesar 0,724, hal ini menunjukan bahwa jika variabel kepemimpinan semakin baik dengan asumsi variabel lain tetap maka variabel kinerja karyawan akan mengalami peningkatan.

a. Hasil Regresi Linier

Sederhana antara kompensasi $\left(\mathrm{X}_{2}\right)$ terhadap kinerja karyawan $(\mathrm{Y})$

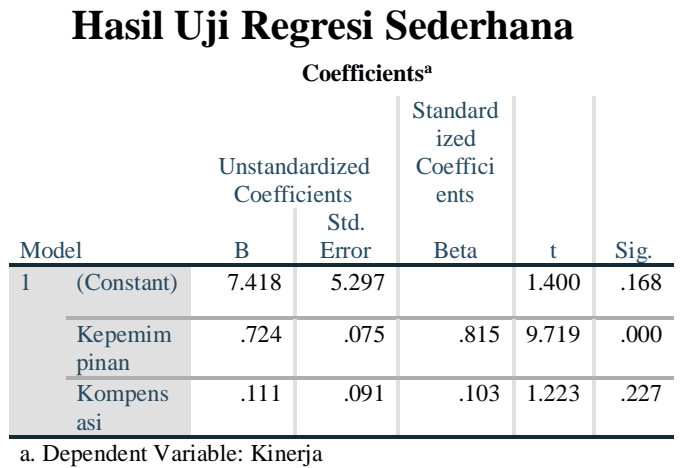

Dari tabel di atas, diperoleh hasil perhitungan sebagai berikut:

Hasil perhitungan uji regresi sederhana diketahui memiliki persamaan regresi yang terbentuk adalah : $\boldsymbol{Y}=\mathbf{7 , 4 1 8}+$ $0,111 X 2$

Sehingga dapat disimpulkan bahwa Variabel kompensasi mempunyai koefisien yang bertanda positif terhadap variabel kinerja karyawan. Koefisien kompensasi memberikan nilai sebesar 0,111 yang berarti bahwa jika variabel kompnesasi semakin baik dengan asumsi variabel lain tetap maka kinerja karyawan akan mengalami peningkatan.

\section{Regresi Linier Berganda Hasil Uji Regresi Berganda

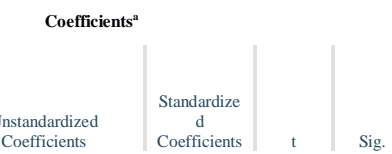




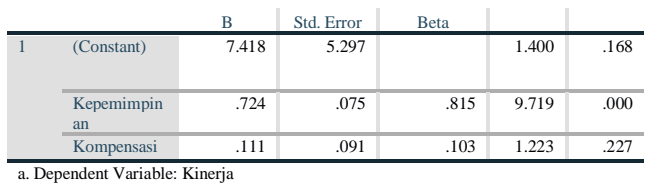

Dari tabel di atas, diperoleh hasil perhitungan sebagai berikut:

Berdasarkan hasil perhitungan uji regresi berganda yang terdapat pada tabel diatas, dapat diketahui persamaan regresi yang terbentuk adalah : $\boldsymbol{Y}=$ $7,418+0,724 X 1+0,111 X 2$

Berdasarkan persamaan regresi berganda yang terbentuk tersebut diatas maka dapat disimpulkan bahwa :

Variabel

kepemimpinan

dan

kompensasi mempunyai koefisien yang bertanda positif terhadap variabel kinerja karyawan. Koefisien variabelkepemimpinanmemberikan nilai sebesar 0,724 ,yang berarti bahwa jika variabel kepemimpinansemakin baik dengan asumsi variabel lain tetap maka variabel kinerja karyawan akan mengalami peningkatan. Koefisien kompensasimemberikan nilai sebesar 0,111yang berarti bahwa jika variabel kompnesasisemakin baik dengan asumsi variabel lain tetap maka kinerja karyawan akan mengalami peningkatan.

4. Uji koefisien korelasi

Korelasi Variabel

Kepemimpinan $\left(\mathbf{X}_{1}\right)$

terhadap kinerja

karyawan (Y).

\begin{tabular}{|l|l|r|r|}
\hline \multicolumn{3}{|c|}{ Correlations } \\
\hline \multicolumn{2}{|c|}{} & \multicolumn{1}{|c|}{$\mathrm{x} 1$} & \multicolumn{1}{|c|}{$\mathrm{Y}$} \\
\hline $\mathrm{x} 1$ & Pearson Correlation & 1 & $.666^{* *}$ \\
\cline { 2 - 4 } & Sig. (2-tailed) & & .000 \\
\cline { 2 - 4 } & $\mathrm{N}$ & $.666^{* *}$ & 50 \\
\hline $\mathrm{Y}$ & Pearson Correlation & .000 & \\
\cline { 2 - 4 } & Sig. (2-tailed) & 50 & \\
\cline { 2 - 4 } & $\mathrm{N}$ & 50 \\
\hline **. Correlation is significant at the 0.01 level (2-tailed). \\
\hline
\end{tabular}

Hasil korelasi pada tabel di atas, menunjukan nilai koefisien korelasi sebesar 0,666, yang berarti variabel
Kepemimpinan $\left(\mathrm{X}_{1}\right)$ memiliki tingkat hubungan yang kuat terhadap variabel kinerja karyawan (Y).

a. Hasil korelasi antara kompensasi $\left(\mathrm{X}_{2}\right)$ terhadap kinerja karyawan (Y).

Korelasi Variabel Kompensasi $\left(\mathbf{X}_{2}\right)$ terhadap kinerja karyawan (Y).

\begin{tabular}{|l|l|r|r|}
\hline \multicolumn{3}{|c|}{ Correlations } \\
\hline \multirow{2}{*}{ x2 } & Pearson Correlation & x2 & \multicolumn{1}{|c|}{ Y } \\
\cline { 2 - 4 } & & 1 & $.634^{* *}$ \\
\cline { 2 - 4 } & Sig. (2-tailed) & & .000 \\
\cline { 2 - 4 } & N & 50 & 50 \\
\hline Y & Pearson Correlation & $.634^{* *}$ & 1 \\
& & & 50 \\
\cline { 2 - 4 } & Sig. (2-tailed) & .000 & \\
\cline { 2 - 4 } & N & 50 & \\
\hline \multirow{2}{*}{$* *$ Correlation is significant at the 0.01 level (2-tailed). } \\
\hline
\end{tabular}

Berdasarkan hasil korelasi pada tabel di atas, maka diperoleh nilai koefisien korelasi sebesar 0,634, artinya variabel Kompensasi $\left(\mathrm{X}_{2}\right)$ memiliki tingkat hubungan yang kuat terhadap variabel kinerja karyawan (Y).

b. Hasil korelasi antara Kepemimpinan $\left(\mathrm{X}_{1}\right)$, Kompensasi $\left(\mathrm{X}_{2}\right)$ dan Kinerja (Y)

Korelasi Variabel Kepemimpinan (X1) dan Kompensasi (X2) terhadap Kinerja (Y)

\begin{tabular}{|l|c|c|c|c|}
\hline \multicolumn{5}{|c|}{ Model Summary } \\
\hline $\begin{array}{l}\text { Mod } \\
\text { el }\end{array}$ & R & R Square & $\begin{array}{c}\text { Adjusted R } \\
\text { Square }\end{array}$ & $\begin{array}{c}\text { Std. Error } \\
\text { of the } \\
\text { Estimate }\end{array}$ \\
\hline 1 & $.666^{\mathrm{a}}$ & .443 & .420 & 3.33646 \\
\hline \multicolumn{7}{|l|}{ a. Predictors: (Constant), kepemimpinan, kompensasi } \\
\hline
\end{tabular}

Hasil korelasi pada tabel di atas, menunjukan nilai koefisien sebesar 0,666, yang berarti variabel Kepemimpinan $\left(\mathrm{X}_{1}\right)$ dan variabel Kompensasi $\left(\mathrm{X}_{2}\right)$ secara simultan memiliki tingkat kekuatan hubungan yang kuat terhadap variabel kinerja karyawan (Y).

\section{Koefisien determinasi (R2)}

Hasil Analisis Koefisien Determinasi Secara Parsial 
Variabel Kepemimpinan $\left(\mathrm{X}_{1}\right)$ Terhadap Kinerja (Y)

\begin{tabular}{|c|c|c|c|c|}
\hline \multicolumn{5}{|c|}{ Model Summary } \\
\hline Model & $\mathrm{R}$ & $\begin{array}{c}\mathrm{R} \\
\text { Squar } \\
\mathrm{e}\end{array}$ & $\begin{array}{l}\text { Adjusted } \\
\text { R Square }\end{array}$ & $\begin{array}{c}\text { Std. } \\
\text { Error of } \\
\text { the } \\
\text { Estimate }\end{array}$ \\
\hline 1 & $.666^{\mathrm{a}}$ & .443 & .432 & 3.30199 \\
\hline
\end{tabular}

Berdasarkan tabel diatas diperoleh koefisien determinasi sebesar 0,443, yang dapat disimpulkan bahwa kontribusi pengaruh antara variabel Kepemimpinan $\left(\mathrm{X}_{1}\right)$ terhadap kinerja karyawan (Y) sebesar 44,3\% sedangkan sisanya $55,7 \%$ dapat dipengaruhi oleh faktor-faktor lain yang tidak diteliti pada penelitian ini.

Hasil Analisis Koefisien Determinasi Secara Parsial Variabel Kompensasi $\left(\mathbf{X}_{2}\right)$ Terhadap Kinerja (Y)

\begin{tabular}{|l|c|c|c|c|}
\hline \multicolumn{5}{|c|}{ Model Summary } \\
\hline Model & $\mathrm{R}$ & $\begin{array}{c}\text { Squar } \\
\mathrm{e}\end{array}$ & $\begin{array}{c}\text { Adjusted } \\
\text { R Square }\end{array}$ & $\begin{array}{c}\text { Std. Error } \\
\text { of the } \\
\text { Estimate }\end{array}$ \\
\hline 1 & $.634^{\mathrm{a}}$ & .402 & .390 & 3.42052 \\
\hline a. Predictors: (Constant), kompensasi \\
\hline
\end{tabular}

Berdasarkan tabel diatas diperoleh koefisien determinasi sebesar 0,402, yang berarti kontribusi pengaruh antara variabel Kompensasi $\left(\mathrm{X}_{1}\right)$ terhadap kinerja karyawan (Y) sebesar 40,2\% sedangkan sisanya 59,8\% dipengaruhi oleh faktor-faktor lain diluar penelitian.

Hasil Analisis Koefisien

Determinasi Secara simultan

Variabel Kepemimpinan $\left(\mathbf{X}_{1}\right)$

dan Kompensasi $\left(X_{2}\right)$ Terhadap Kinerja Karyawan (Y)

\begin{tabular}{|c|c|c|c|c|}
\hline \multicolumn{5}{|c|}{ Model Summary } \\
\hline Model & $\mathrm{R}$ & $\begin{array}{c}\mathrm{R} \\
\text { Squar } \\
\mathrm{e}\end{array}$ & $\begin{array}{c}\text { Adjusted } \\
\text { R } \\
\text { Square }\end{array}$ & $\begin{array}{c}\text { Std. } \\
\text { Error of } \\
\text { the } \\
\text { Estimate }\end{array}$ \\
\hline 1 & $.666^{\mathrm{a}}$ & .443 & .420 & 3.33646 \\
\hline
\end{tabular}

Dari tabel model summary SPSS 25 maka dapat diketahui nilai $\mathrm{R}$ Square sebesar 0,443 atau sebesar 44,3\%, yang menunjuka Kepemimpinan dan Kompensasi memberikan pengaruh terhadap kinerja sedangkan sisanya sebesar 55,7\% dipengaruhi oleh variabel lain yang tidak digunakan dalam penelitian ini.

\section{Uji Hipotesis}

\section{Uji t Parsial}

Hasil Uji t Variabel Kepemimpinan (X1) terhadap Kinerja Karyawan (Y)

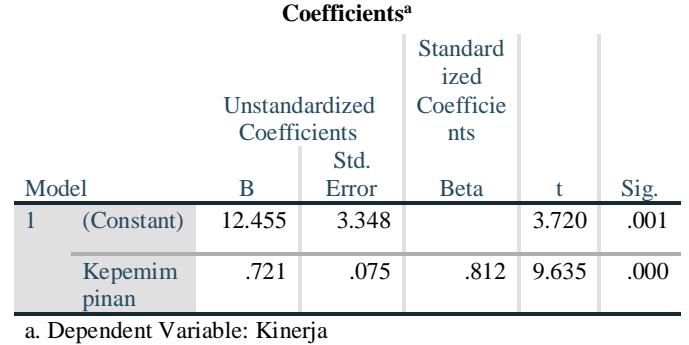

Tabel diatas menunjukan, nilai $t$ hitung sebesar 9,635 lebih tinggi dari nilai $t$ tabel yaitu 2,011. Taraf signifikansi variabel kepemimpinan adalah $(0,000)$ lebih kecil dari 0,05 , hal ini berarti hipotesis penelitian ini menerima $\mathrm{Ha}_{1}$ dan menolak $\mathrm{H}_{01}$. Dengan demikian dapat disimpulkan bahwa hipotesis $\mathrm{Ha}_{1}$ "Kepemimpinan mempunyai pengaruh positif dan signifikan terhadap Kinerja Karyawan".

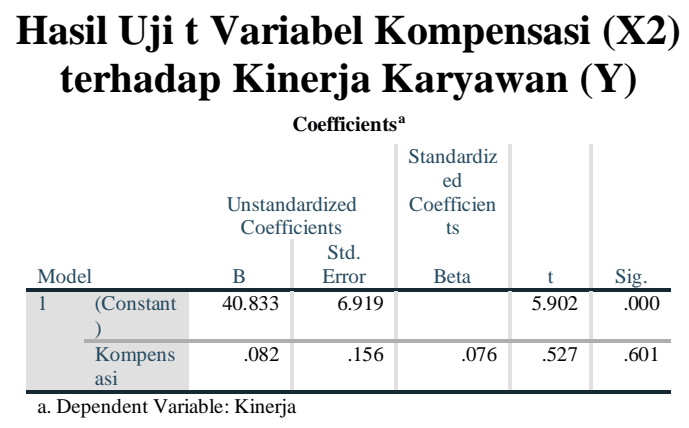

Dari tabel diatas, diperoleh hasil perhitungan analisis sebagai berikut : Hasil pengujian hipotesis kompensasi menunjukkan nilai $t$ hitung sebesar 
0,527 lebih rendah dari nilai $t$ tabel yaitu 2,011. Taraf signifikansi kompensasi adalah $(0,601)$ lebih besardari 0,05 , yang berarti bahwa hipotesis dalam penelitian ini menolak $\mathrm{H}_{\mathrm{a} 2}$ dan menerima $\mathrm{H}_{02}$. Dengan demikian dapat disimpulkan bahwa hipotesis $\mathrm{H}_{02}$ "kompensasi tdiak mempunyai pengaruh positif terhadap kinerja karyawan" diterima.

\section{Uji F Simultan}

\section{Hasil Uji F (Simultan)}

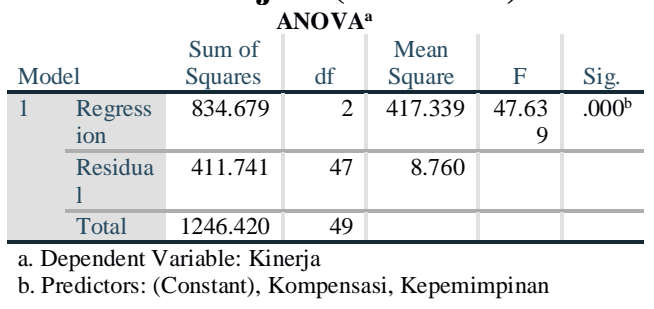

\section{PENUTUP}

\section{A. Kesimpulan}

1. Kepemimpinan mempunyai pengaruh positif dan signifikan terhadap Kinerja Karyawan, dimana hasil pengujian hipotesis secara parsial (uji t), diperoleh nilai t hitung sebesar 9,635 yang lebih tinggi dari nilai $t$ tabel sebesar 2,011. Tingkat signifikansi variabel kepemimpinan adalah $(0,000)$ lebih kecil dari 0,05. Nilai koefisien korelasi sebesar 0,666, artinya variabel Kepemimpinan (X1) memiliki tingkat hubungan yang kuat. Nilai koefisien determinasi sebesar $44,3 \%$ sedangkan sisanya $55,7 \%$.

2. Kompensasi mempunyai pengaruh tetapi tidak signifikan terhadap Kinerja Karyawan, dimana hasil pengujian hipotesis secara parsial (uji t), diperoleh nilai $t$ hitung sebesar 0,527 lebih rendah dari nilai $t$ tabel yaitu
1,675. Taraf signifikansi kompensasi adalah $(0,601)$ lebih besar dari 0,05. nilai koefisien korelasi sebesar 0,634, artinya variabel Kompensasi (X2) memiliki tingkat hubungan yang kuat. Nilai koefisien determinasi sebesar 40,2\% sedangkan sisanya $59,8 \%$.

3. Kepemimpinan dan Kompensasi mempunyai pengaruh secara bersama-sama terhadap kinerja karyawan, dimana nilai $\mathrm{F}$ hitung $=47,639$ lebih tinggi dari nilai $\mathrm{F}$ tabel yaitu 2,78. Taraf signifikansi seluruh variabel bebas secara simultan $(0,000)$ lebih kecil dari 0,05 , yang berarti hipotesis dalam penelitian ini menerima $\mathrm{Ha}$ dan menolak $\mathrm{H}_{0}$. Dengan demikian dapat disimpulkan bahwa Hipotesis 3 "kepemimpinan dan kompensasi mempunyai pengaruh postif dan signifikan terhadap kinerja karyawan" diterima. Berdasarkan hasil perhitungan uji regresi berganda yang terdapat pada tabel diatas, dapat diketahui persamaan regresi yang terbentuk adalah : $\boldsymbol{Y}=$ $7,418+0,724 X 1+0,111 X 2$ dan berdasarkan uji regresi linier berganda diketahui bahwa nilai $R$ Square $\left(R^{2}\right)$ adalah sebesar 0,670dimana nilai tersebut masuk pada kategori kuat. Sehingga, dapat disimpulkan bahwa variabel kepemimpinan dan kompensasisecara simultan memiliki pengaruh positif terhadap kinerja dengan perolehan nilai sebasar 67\%, sedangkan sisanya yaitu sebesar $33 \%$ ditentukan oleh faktor- 
faktor lain yang tidak diteliti dalam penelitian ini.

\section{B. Saran}

1. Diharapkan pimpinan sering menetapkan serangkaian tujuan dan mengajak karyawan untuk berpartisipasi mencapai tujuan perusahaan

2. Diharapkan perusahaan memperhatikan pemberian tunjangan para karyawan.

3. Diharapkan karyawan lebih memperhatikan hasil kerjanya sesuai dengan kompetensi yang ada pada perusahaan.

\section{DAFTAR PUSTAKA}

Anwar Sanusi, 2012, Metode Penelitian Bisnis, Salemba Empat, Jakarta

Arikunto, Suharsimi. 2011. Prosedur Penelitian. Jakarta: Rineka Cipta

Bachtiar, Doni. 2017. "Pengaruh Motivasi Dan Lingkungan Kerja Terhadap Kinerja Karyawan”. "Management Analysis Journal". Vol. 1 No. 1. http://journal.unnes.ac.id/sju/ind ex.php/maj.

Dessler, Gary. 2013. Manajemen Sumber Daya Manusia. Jakarta: Salemba Empat

Donni Juni Priansa. 2011. Perencanaan dan Pengembangan SDM.Penerbit : Alfabeta Bandung.

Edy,Sutrisno,2015,Manajemen Sumber Daya Manusia, Kencana Prenada Media Group, Jakarta.

Ghozali. Imam. 2012. Aplikasi Analisis Multivariate Dengan Program
SPSS. Cetakan Empat. Semarang: Badan Penerbitan Univesitas Diponegoro.

Handoko. T. Hani. 2013. Manajemen. Yogyakarta: BPFE.

Harsuko.

2011,MendongkrakMotivasidan

Kinerja:

PendekatanPemberdayaanSDM, UB Press,Malang.

Hasibuan, Malayu. 2012. "Manajemen Sumber Daya manusia". Jakarta: PT Bumi Aksara.

Hasibuan. M. Malayu SP. 2013. Manajemen Personalia dan Sumber Daya Manusia.Jakarta: Bumi Aksara

Istijanto. 2014. Riset Sumber Daya Manusia. Jakarta: PT. Gramedia Pustaka

Laksmi Riani, Asri. 2013. Manajemen SDM Masa Kini, Yogyakarta : Graha Ilmu.

Mangkunegara, A.A. Anwar Prabu. 2012. "Manajemen Sumber Daya Perusahaan". Cetakan Kesepuluh. Bandung: PT Remaja Rosdakarya

Marwansyah. 2016.Manajemen Sumber Daya Manusia, Bandung: ALFABET

Mondy, R Wayne, Robert M. Noe, Shane R. Premeaux. 2014. Human Resource Management 7th Edition. Prentice Hall.

Pasaribu, V. L. D., Krisnaldy, K., \& Warasto, H. N. (2020). Pengaruh 
Gaya Kepemimpinan, Disiplin Kerja Dan Kompensasi Terhadap Kinerja Pegawai (Studi kasus kelurahan Pisangan Ciputat). Jurnal Disrupsi Bisnis: Jurnal Ilmiah Prodi Manajemen, Fakultas Ekonomi, Universitas Pamulang, 3(1).

Setiawan, Ferry dan Dewi, Kartika. 2014. Pengaruh Kompensasi Dan Lingkungan Kerja Terhadap Kinerja Karyawan pada CV. Berkat Anugrah.Jurnal. Denpasar: Universitas Udayana

Sinambela, Lijan Poltak. 2016. Manajemen Sumber Daya Manusia. Jakarta: PT Bumi Aksara

Sugiyono, 2013. "Metode Penelitian Bisnis". Bandung: CV. Alfabeta

Sugiyono. 2016. "Metode Penelitian Kualitatif Kuantitatif dan R\&D”. Bandung: CV. Alfabeta.

Veithzal Rivai. 2014. "Manajemen Sumber Daya Manusia untuk Perusahaan". Bandung: PT. Remaja Rosda Kary

Wibowo. 2016. "Manajemen Kinerja". Jakarta: PT. Rajagrafindo Persada.

Widiyanto, Joko. 2018. SPSS For Windows Untuk Analisis Data Statistik dan Penelitian. Surakarta: Labolatorium Komputer FKIP UMS 